\title{
Analisis Ketersediaan Air Waduk Gadjah Mungkur dengan Adanya Pembangunan Intake dan Jaringan Pipa Trasmisi Wosusokas
}

\author{
B.K.P. Cantik ${ }^{a *}$, I.R. Fitriana ${ }^{b}$, N. Diandra ${ }^{a}$, S. Valentino ${ }^{a}$ dan A.K. Tambing ${ }^{a}$ \\ a Jurusan Teknik Sipil, Fakultas Teknik Universitas Pradita, Tangerang, Indonesia 15810 \\ ${ }^{b}$ Jurusan Teknik Sipil, Fakultas Teknik Universitas Selamat Sri, Kendal, Indonesia, 51351 \\ ${ }^{*}$ Corresponding author's e-mail: bella.paulina@pradita.ac.id
}

Received: 14 August 2021; revised: 22 August 2021; accepted: 25 August 2021

\begin{abstract}
Gadjah Mungkur Reservoir is one of the multipurpose reservoirs built by damming the flow of the Bengawan Solo River. The Gadjah Mungkur Reservoir has existed for a long time with the main purpose of controlling flooding, but over time, this reservoir is also useful as a hydropower plant, irrigation, and also to meet the raw water needs of Wonogiri City. The potential of the Gadjah Mungkur Reservoir itself in meeting the needs of drinking water is an essential function in the people's life around the reservoir. Therefore, the expansion of the scope of providing drinking water can be used to develop the potential of the Gadjah Mungkur Reservoir. This coverage expansion was realized through the construction of the Wosusokas intake and transmission pipeline network to drinking water receiving areas, namely Wonogiri, Sukoharjo, Solo, and Karanganyar, with service coverage of drinking water access resepectively $\pm 78,38, \pm 70,97 \%$, $\pm 81,85 \%$, and $\pm 70,97 \%$. This study aims to analyze the water availability of the Gadjah Mungkur Reservoir with additional coverage for drinking water services. The method used is a simple reservoir routing calculation by processing secondary data obtained in the form of inflow, outflow, and reservoir storage characteristics. The results of the analysis show that elevation variations with the construction of the Wosusokas intake and transmission pipeline have an annual average of $+132,56 \mathrm{~m}$ in 2017, with a reservoir storage volume reaching 216,27 $\mathrm{MCM}$ and $+134,29 \mathrm{~m}$ in 2018, with a reservoir storage volume reaching 284,92 MCM. However, there are some elevation values that exceed $+138,0$ m, namely at February to March 2018. However, overall, the results of the analysis show that the Wosusokas construction can increase the potential utilization of the Gadjah Mungkur Reservoir without endangering the reservoir with water level fluctuations that can still be controlled and in accordance with the regulation of reservoir water level.
\end{abstract}

Keywords: drinking water, water level elevation, reservoir, Wosusokas.

\begin{abstract}
Abstrak: Waduk Gadjah Mungkur merupakan salah satu waduk serbaguna yang dibangun dengan membendung aliran Sungai Bengawan Solo. Waduk Gadjah Mungkur sudah ada sejak lama dengan tujuan utama adalah sebagai pengendali banjir, namun seiring berjalannya waktu, waduk ini juga bermanfaat sebagai PLTA, irigasi, dan juga untuk memenuhi kebutuhan air baku bagi Kota Wonogiri. Potensi Waduk Gadjah Mungkur sendiri dalam mencukupkan kebutuhan air baku menjadi suatu fungsi esensial dalam kehidupan masyarakat di sekitar waduk. Oleh karena itu, perluasan cakupan pemberian air baku dapat digunakan untuk mengembangkan potensi dari Waduk Gadjah Mungkur. Perluasan cakupan ini direalisasikan melalui pembangunan intake dan jaringan pipa transmisi Wosusokas pada daerah penerima air minum, yaitu Wonogiri, Sukoharjo, Solo, dan Karanganyar, dengan cakupan pelayanan akses aman air minum berturut-turut sebesar $\pm 78,38, \pm 70,97 \%, \pm 81,85 \%$, dan $\pm 70,97 \%$. Penelitian ini bertujuan untuk menganalisis ketersediaan air Waduk Gadjah Mungkur dengan adanya tambahan cakupan untuk pelayanan air minum. Metode yang digunakan adalah perhitungan penelusuran waduk sederhana dengan mengolah data-data sekunder yang didapat berupa inflow, outflow, dan karakteristik tampungan waduk. Hasil analisis menunjukkan bahwa variasi elevasi dengan adanya pembangunan intake dan jaringan pipa transmisi Wosusokas memiliki rerata tahunan $+132,56 \mathrm{~m}$ pada tahun 2017, dengan volume tampungan waduk mencapai 216,27 MCM dan $+134,29$ m pada tahun 2018, dengan volume tampungan waduk mencapai 284,92 MCM. Namun, terdapat nilai elevasi yang melebihi +138,0 m yaitu pada bulan Februari hingga Maret pada tahun 2018. Meskipun demikian, secara keseluruhan, hasil analisis menunjukkan bahwa adanya pembangunan tersebut dapat meningkatkan pemanfaatan potensi Waduk Gadjah Mungkur tanpa membahayakan waduk dengan fluktuasi elevasi muka air yang masih dapat dikontrol dan sesuai dengan aturan elevasi muka air bendungan pada saat pembukaan pintu.
\end{abstract}

Kata kunci: air minum, elevasi muka air, waduk, Wosusokas.

\section{Pendahuluan}

Waduk Gadjah Mungkur atau lebih dikenal dengan Waduk Wonogiri merupakan salah satu waduk serbaguna yang berada di Daerah Aliran Sungai (DAS) Bengawan Solo, dengan luas Daerah Tangkapan Air (DTA) $1.350 \mathrm{~km}^{2}$. Awal mula waduk dibangun dengan fungsi utama sebagai pengendali banjir di Sungai Bengawan Solo, namun hingga saat ini Waduk Gadjah Mungkur menjadi waduk serbaguna dengan fungsi tidak hanya sebagai pengendali banjir, tetapi juga sebagai Pembangkit Listrik Tenaga Air (PLTA) sebesar 12,4 MW, dan juga melayani daerah irigasi yang dialirkan ke Bendung Colo, dengan luas 23.600 Ha. Selain itu, Waduk Gadjah Mungkur juga digunakan untuk memenuhi kebutuhan air baku untuk Kota Wonogiri [1]. Namun, Waduk Gadjah Mungkur juga mengalami permasalahan sedimentasi yang mengancam penurunan efektivitas dan efisiensi pemanfaatan air terhadap fungsi waduk. Oleh karenanya dibangun proyek pembangunan closure dike di dalam waduk untuk mengatasi permasalahan sedimentasi tersebut. Adanya pembangunan closure dike tersebut diharapkan menjadi solusi yang tepat sehingga air waduk dapat dimanfaatkan dengan lebih maksimal, 
termasuk juga dalam pemanfaatan pembangunan intake dan jaringan pipa transmisi Wosusokas.

Wosusokas direncanakan akan membantu untuk memenuhi kebutuhan air baku pada beberapa daerah. Skema pipa transmisi Wosusokas dapat dilihat pada Gambar 1. Gambar 1 menunjukkan gambar rencana atau konsep desain awal dari Proyek Wosusokas, namun pada rencana aplikasinya, Sragen sudah tidak termasuk dalam daerah yang mendapat air baku dari pipa transmisi Wosusokas. Rencana jaringan pipa transmisi Wosusokas ini direalisasikan sebagai pemenuhan kebutuhan terhadap meningkatnya jumlah penduduk yang berbanding lurus dengan permintaan pelayanan air minum. Meskipun begitu, adanya permintaan pelayanan air minum yang meningkat juga akan diikuti dengan meningkatnya biaya pengolahan air minum, sedangkan kemampuan masyarakat sekitar umumnya masih rendah.

Pengambilan air pada jaringan pipa transmisi Wosusokas mengandalkan air dari Waduk Gadjah Mungkur. Adanya pembangunan closure dike sebagai solusi dalam permasalahan sedimentasi Waduk Gadjah Mungkur sejalan dengan rencana pembangunan jaringan pipa transmisi Wosusokas. Meskipun begitu, pembangunan closure dike tidak memiliki pengaruh apapun terhadap alokasi pembagian air yang diberikan kepada daerah-daerah yang mendapat air baku dari jaringan pipa transmisi Wosusokas.

Pembangunan intake dan jaringan pipa transmisi Wosusokas sebagai Sistem Penyediaan Air Minum (SPAM) Regional dalam upaya untuk memenuhi ketersediaan air baku beberapa daerah dan dalam upaya mencapai target yang tercantum dalam Millennium Development Goals
(MDGs), sehingga tujuan adanya proyek pembangunan intake dan jaringan pipa transmisi Wosusokas adalah sebagai berikut [2].

a) Memberikan pelayanan air minum di Wonogiri, dengan cakupan pelayanan akses aman air minum sebesar $\pm 78,38 \%$.

b) Memberikan pelayanan air minum di Sukoharjo, dengan cakupan pelayanan akses aman air minum sebesar $\pm 70,97 \%$.

c) Memberikan pelayanan air minum di Solo, dengan cakupan pelayanan akses aman air minum sebesar $\pm 81,85 \%$.

d) Memberikan pelayanan air minum di Karanganyar, dengan cakupan pelayanan akses aman air minum sebesar $\pm 70,97 \%$.

Pengambilan air Wosusokas tetap mengandalkan ketersediaan air dari Waduk Gadjah Mungkur, oleh karenanya perhitungan ketersediaan air disesuaikan dengan adanya pembangunan intake dan jaringan pipa transmisi Wosusokas dikarenakan fungsi waduk bertambah.

\section{Metode Penelitian}

\subsection{Lokasi Penelitian}

Penelitian ini berfokus pada pembangunan intake dan jaringan pipa transmisi Wosusokas di Kabupaten Wonogiri. Jaringan pipa transmisi Wosusoaks berlokasi di Kelurahan Wuryorejo dan Desa Sendang, Kecamatan Wonogiri, Kabupaten Wonogiri, Provinsi Jawa Tengah (Gambar 1). Jaringan pipa transmisi Wosusokas tidak hanya melayani Wonogiri namun juga tiga (3) daerah lainnya, yaitu Sukoharjo, Solo, dan Karanganyar.

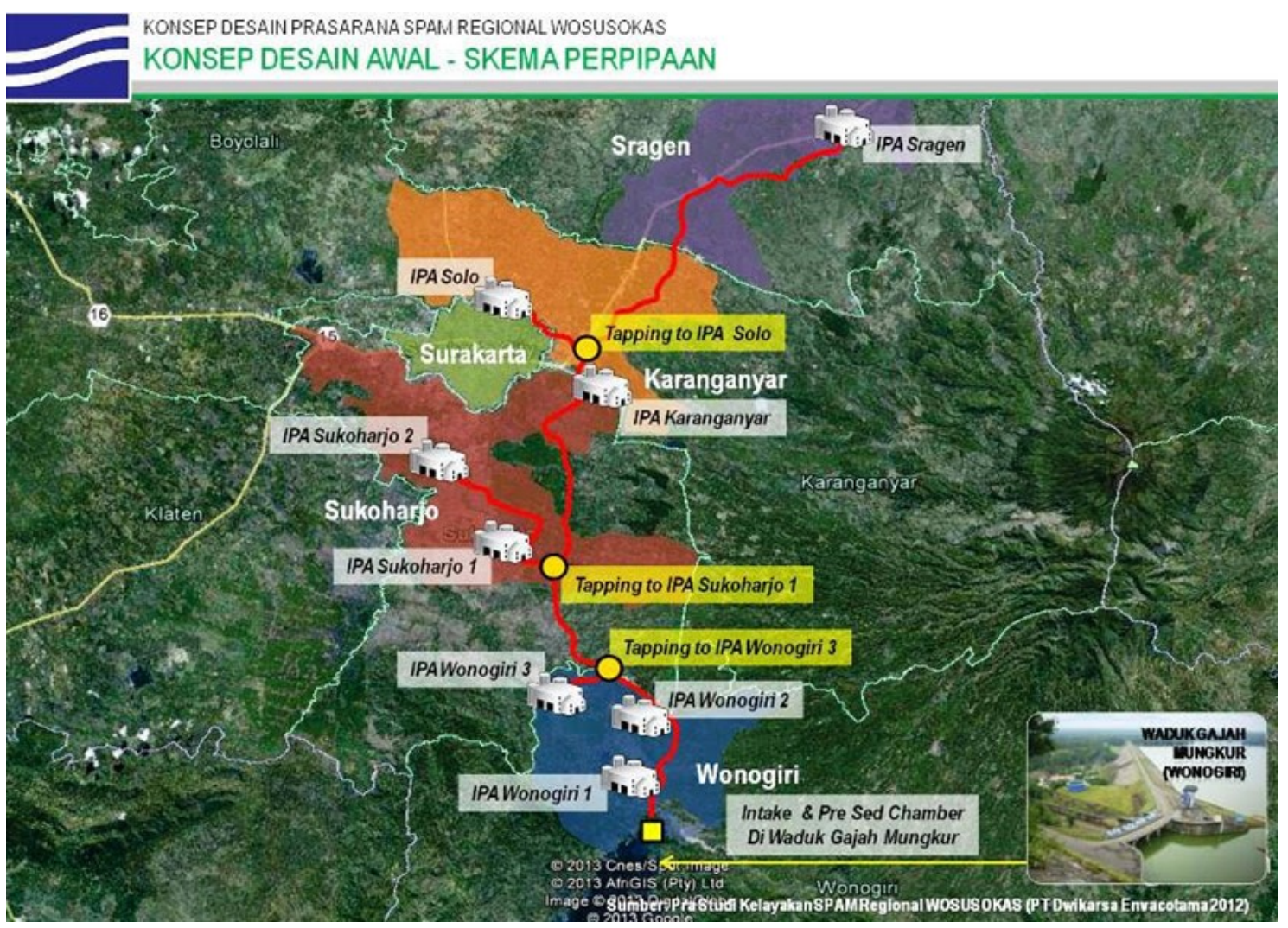

Gambar 1. Jaringan Pipa Transmisi Wosusokasi [3] 


\subsection{Data}

Data umum proyek pembangunan intake dan jaringan pipa transmisi Wosusokas di Kabupaten Wonogiri dapat dilihat pada Tabel 1. Data yang digunakan dalam analisis penelitian ini adalah data sekunder yang diambil dari Januari 2017 sampai dengan Desember 2018. Analisis yang dilakukan adalah dengan menggunakan penelusuran waduk (reservoir routing) sederhana dengan menganalisis kondisi selama periode yang ditinjau. Data yang dikumpulkan adalah data yang didapat dari Balai Besar Wilayah Sungai (BBWS) Bengawan Solo. Berikut merupakan data-data yang dibutuhkan dalam analisis.

a. Data inflow waduk

b. Data elevasi rencana

c. Data outflow turbin

d. Data outflow spillway

e. Data outflow Hollow Jet Valve (HJV)

f. Data tampungan awal waduk (sebelum November 2018)

Tabel 1. Data umum proyek Wosusokas [4-5]

\begin{tabular}{|c|c|c|}
\hline \multirow{6}{*}{ INTAKE } & \multicolumn{2}{|c|}{ Dermaga panjang $122 \mathrm{~m}$, pondasi bore pile sebanyak 66 titik dan plat beton K-300 } \\
\hline & \multicolumn{2}{|c|}{4 pompa turbin vertikal @,500 L/detik, head 95 m } \\
\hline & \multicolumn{2}{|c|}{3 pompa beroperasi, 1 cadangan } \\
\hline & \multicolumn{2}{|c|}{2 genset@2250kVA } \\
\hline & \multicolumn{2}{|c|}{ Panel pompa, genset, trafo, dan motor pompa pada elevasi $+139,5 \mathrm{~m}$} \\
\hline & \multicolumn{2}{|c|}{ Suction head pompa pada elevasi $+126 \mathrm{~m}$} \\
\hline \multirow{10}{*}{ PIPA TRANSMISI } & Jumlah & 3 Pipa \\
\hline & Panjang & $\pm 1.850 \mathrm{~m}$ per pipa \\
\hline & \multirow{8}{*}{ Spesifikasi } & GIP ø $600 \mathrm{~mm}$, tebal $12,7 \mathrm{~mm}$ \\
\hline & & Steel Quality SS400 \\
\hline & & Spesifikasi AWWA C200 / SNI 0039: 2013 \\
\hline & & Spiral / ERW (Electric Resistant Welding) Pipe \\
\hline & & Working Pressure 20,31 bar \\
\hline & & Maximum Test Pressure 30,47 bar \\
\hline & & Bursting Test Pressure 83,33 bar \\
\hline & & Coating galvanis dua sisi \\
\hline \multirow{5}{*}{$\begin{array}{l}\text { RESERVOIR } \\
\text { (Menggunakan Silo) }\end{array}$} & Kapasitas & $1500 \mathrm{~m}^{3}$ per silo \\
\hline & Jumlah & 4 buah \\
\hline & \multirow{3}{*}{ Spesifikasi } & Terbuat dari FRP (Fiberglass Reinforced Plastic) \\
\hline & & Diameter $16 \mathrm{~m}$, tinggi $9 \mathrm{~m}$ \\
\hline & & Tumpuan plat beton dengan pondasi drill shaft sebanyak 100 titik \\
\hline
\end{tabular}

Data-data tersebut di atas dikumpulkan dan diolah dalam perhitungan analisis untuk melihat grafik perbandingan antara elevasi, outflow, dan inflow untuk Waduk Wonogiri. Adanya keterbatasan data pada tahun tertinjau maka diperlukan data tambahan berupa kurva linier antara tampungan dan elevasi dari data pada tahun tertinjau.

\subsection{Metode dan Tahapan Penelitian}

Penelitian ini dilakukan dengan pengolahan data sederhana. Metode penelitian yang digunakan pada penelitian ini adalah kuantitatif deskriptif, dimana pendekatan-pendekatan analisis yang dilakukan adalaha dengan pendekatan Analisis Data Sekunder (ADS) [6-9]. Hal ini disebabkan pengumpulan data yang dilakukan adalah pengumpulan data sekunder dan tidak ada data primer atau pengambilan langsung di lapangan. Tahapan analisis penelitian ini dapat dilihat pada Gambar 2.

Variabel-variabel yang hendak diperhitungkan antara lain adalah volume masuk, volume keluar, dan elevasi yang didapat dari persamaan kurva linier yang didapat dari data sekunder. Perhitungan volume yang masuk ke waduk dihitung berdasarkan inflow yang masuk ke waduk pada periode yang sama dengan tahun yang ditinjau [10-13].
Volume yang masuk perlu untuk diperhitungkan untuk mengetahui besaran air yang masuk ke waduk sehingga pada musim kemarau, dapat untuk menaikkan elevasi, dan pada saat musim hujan dapat sebagai pengendali banjir [9-10]. Persamaan untuk menghitung volume masuk adalah dengan konversi satuan dari inflow yang memiliki satuan $\mathrm{m}^{3} / \mathrm{s}$ menjadi satuan volume yaitu $\mathrm{m}^{3}$.

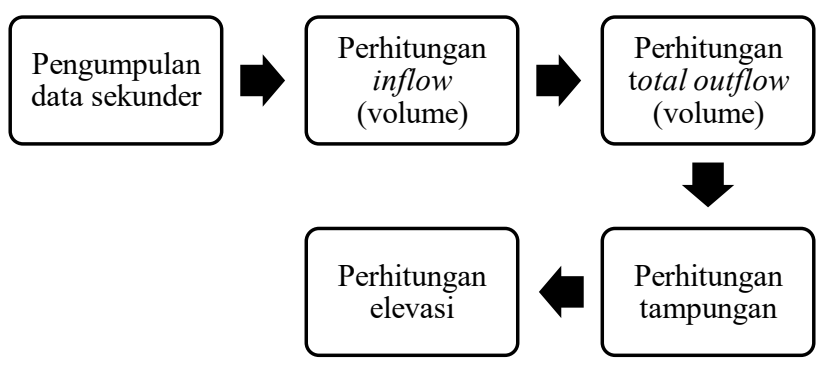

Gambar 2. Tahapan analisis

Untuk perhitungan volume yang keluar waduk disesuaikan dengan pelepasan air waduk (release) dan juga bergantung pada inflow yang masuk ke waduk, apakah sudah mumpuni untuk dikeluarkan dan dialirkan [14-15]. Sehingga, inflow, outflow, dan elevasi memiliki 
ketergantungan satu dengan yang lain sehingga tidak dapat dipisahkan. Outflow Waduk Gadjah Mungkur berasal dari tiga (3) pintu pengeluaran yaitu turbin, spillway, dan Hollow Jet Valve (HJV). Namun ketiga pintu tersebut tidak dibuka secara bersaman namun bergantian disesuaikan dengan debit outflow yang dikeluarkan dan kebutuhan akan outflow untuk dikeluarkan. Perhitungan volume outflow sama dengan perhitungan volume inflow, yaitu dengan mengonversikan outflow total dari $\mathrm{m}^{3} / \mathrm{s}$ ke satuan volume yaitu $\mathrm{m}^{3}$.

Persamaan antara tampungan dan elevasi didapatkan setelah perhitungan inflow, outflow, dan tampungan yang disesuaikan dengan periode tahun tertinjau, sehingga dari perhitungan yang sudah dilakukan, didapatkan kurva linier yang dapat dilihat pada Gambar 3.

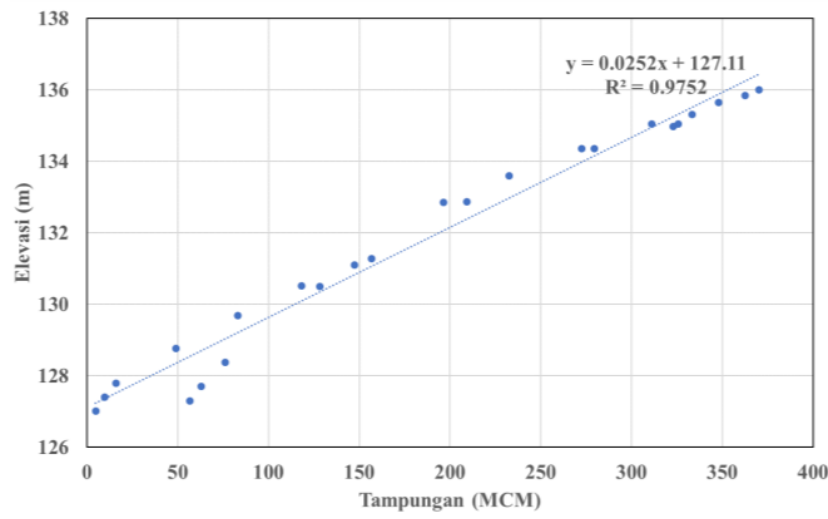

Gambar 3. Persamaan linier tampungan dan elevasi

Pada Gambar 3 dapat dilihat bahwa persamaan yang terbentuk untuk tampungan dan elevasi yang akan digunakan dalam perhitungan dapat dilihat pada Persamaan (1) dan (2)

$$
y=0,0252 x+127,11
$$

dimana:

$\mathrm{y}=$ Elevasi $(\mathrm{m})$

$\mathrm{X}=$ Storage atau tampungan $\left(\mathrm{m}^{3}\right)$

Bila persamaan (1) disubstitusikan dalam bentuk elevasi dan tampungan, maka diperoleh persamaan:

$$
\mathrm{E}=0,0252 \mathrm{~S}+127,11
$$

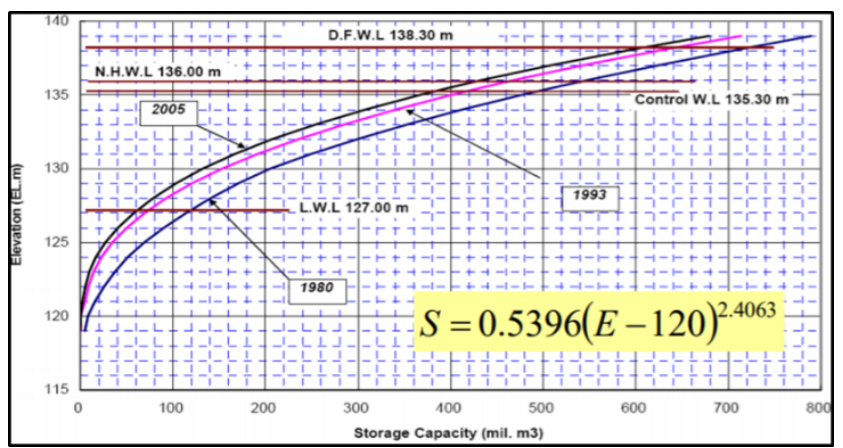

Gambar 4. Karakteristik Tampungan Waduk Gadjah Mungkur [1]

Persamaan tersebut didapatkan dari data-data yang tidak dihitung secara langsung, melainkan didapatkan dari data-data sekunder yang ada yaitu dari Januari 2017 sampai dengan Desember 2018. Selain itu, diketahui terdapat persamaan karakteristik tampungan Waduk Gadjah Mungkur dari penelitian sebelumnya yang dapat dilihat pada Gambar 4. Selain itu juga terlihat bahwa persamaan yang dapat digunakan untuk karakteristik tampungan waduk adalah sebagai berikut:

$$
\mathrm{S}=0,5396(\mathrm{E}-120)^{2,4063}
$$

Persamaan (3) di atas merupakan persamaan dari kurva karakteristik tampungan Waduk Gadjah Mungkur, oleh karena itu perumusan ini dijadikan landasan untuk mencari elevasi, sehingga persamaan tersebut menjadi Persamaan (4) berikut:

$$
\mathrm{E}=120+e^{\left(\frac{\ln \left(\frac{S}{0,5396}\right)}{2,4063}\right)}
$$

Tahun data yang hendak diolah pada analisis penelitian ini adalah dari tahun 2017 sampai dengan tahun 2018, dikarenakan keterbatasan data sekunder yang didapat dari pengelola waduk. Berikut data yang diketahui untuk analisis.

a) Volume akhir (2016) $\quad=162,2136436 \mathrm{MCM}$

b) Kapasitas tampungan $\quad=440 \mathrm{MCM}$

c) Vol. tampungan min. $\quad=120 \mathrm{MCM}$

d) Target release Wosusokas $\quad=1,45 \mathrm{~m}^{3} / \mathrm{s}$

e) Angka Min. Operation Level $=136 \mathrm{~m}$

Berdasarkan data sekunder tersebut tersebut, maka angka outflow untuk Wosusokas akan konstan 1,45 $\mathrm{m}^{3} / \mathrm{s}$. Nilai tersebut akan dipakai dalam analisis perhitungan sebagai aliran keluar dari waduk yang dikeluarkan sebagai kebutuhan air konstan untuk jaringan pipa transmisi Wosusokas.

\section{Hasil dan Pembahasan}

\subsection{Inflow (Aliran Masuk ke Waduk)}

Data inflow atau aliran masuk ke waduk pada tahun 2017 dan tahun 2018 dapat dilihat pada Gambar 5.
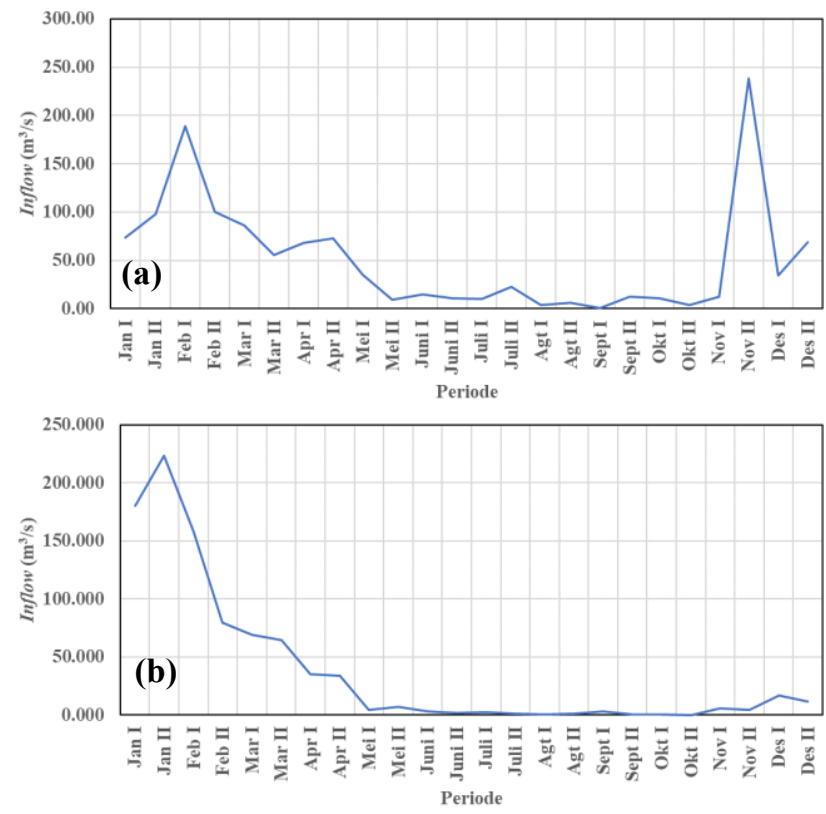

Gambar 5. Inflow Waduk Gadjah Mungkur: (a) Tahun 2017; (b) Tahun 2018 
Dari Gambar 5 terlihat perbedaan nilai inflow untuk aliran masuk ke waduk dari tahun 2017 dan tahun 2018. Pada gambar tersebut ditunjukkan bahwa nilai inflow tertinggi pada tahun 2017 adalah pada akhir tahun, sedangkan di tahun 2018, nilai inflow tertinggi adalah pada awal tahun. Namun sesungguhnya menunjukkan pola fluktuasi yang tidak cukup berbeda dari tahun 2017 dan 2018.

\subsection{Outflow (Aliran Keluar Waduk)}

Aliran keluar waduk didapatkan dari nilai outflow waduk yang hendak dialirkan sesuai dengan pintu yang

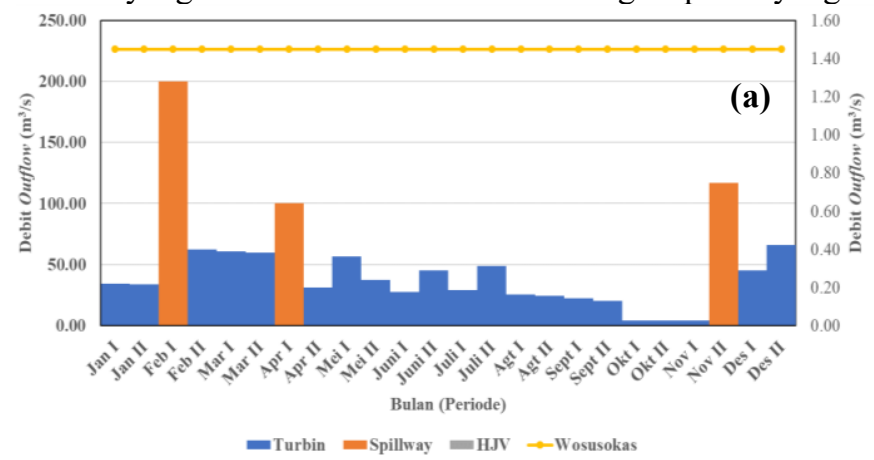

Gambar 6. Outflow Waduk Gadjah Mungkur: (a) Tahun 2017; (b) Tahun 2018

\subsection{Tampungan dan Elevasi}

Perhitungan hasil tampungan dan elevasi didapat dari perhitungan sebelumnya yaitu inflow dan outflow. Sebelum mengetahui kedua variabel tersebut, maka tampungan tidak dapat dihitung, begitu juga dengan elevasi. Tampungan dihitung dengan menambahkan inflow dan perubahan tampungan yang terjadi $(\Delta S)$. Perubahan tampungan sendiri didapatkan dari nilai selisih dari aliran yang masuk ke waduk dengan aliran yang keluar dari waduk. Pada prosesnya, perubahan tampungan ini dapat menghasilkan nilai negatif (-), namun hal ini bukan berarti bahwa waduk dibuka dan kebutuhannya. Pada tahun 2017 dan 2018, HJV tidak dibuka, oleh karenanya nilai outflow waduk didapatkan dari pembukaan turbin, spillway, dan juga untuk kebutuhan air baku Wosusokas. Grafik outflow Waduk Gadjah Mungkur pada tahun 2017 dan tahun 2018 dapat dilihat pada Gambar 6 .

Gambar 6 menunjukkan bahwa HJV tidak dibuka pada dua (2) tahun tertinjau dikarenakan outflow pada Waduk Gadjah Mungkur masih dimungkinkan untuk dibuka melalui spillway.

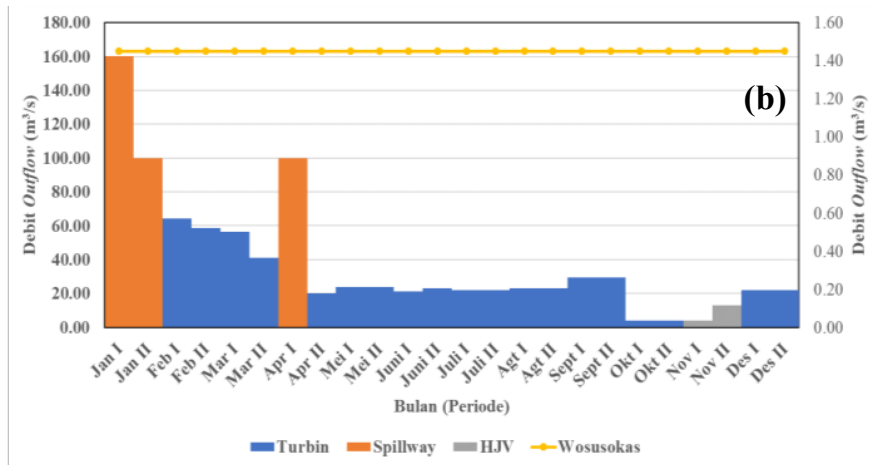

tersebut mengalami kekurangan air yang ada di dalamnya, melainkan adanya nilai negatif tersebut menandakan bahwa nilai outflow atau aliran yang keluar dari waduk melebihi nilai inflow atau aliran yang masuk ke waduk. Hal tersebut bukanlah hal yang membahayakan bila dalam keadaan elevasi yang masih diatur dengan baik, mengingat bahwa Waduk Gadjah Mungkur adalah waduk serbaguna dimana waduk tersebut tidak hanya bermanfaat untuk pengendali banjir tetapi juga memberi atau mencukupkan kebutuhan air pada masyarakat sekitar. Grafik tampungan pada tahun 2017 dan 2018 dapat dilihat pada Gambar 7.

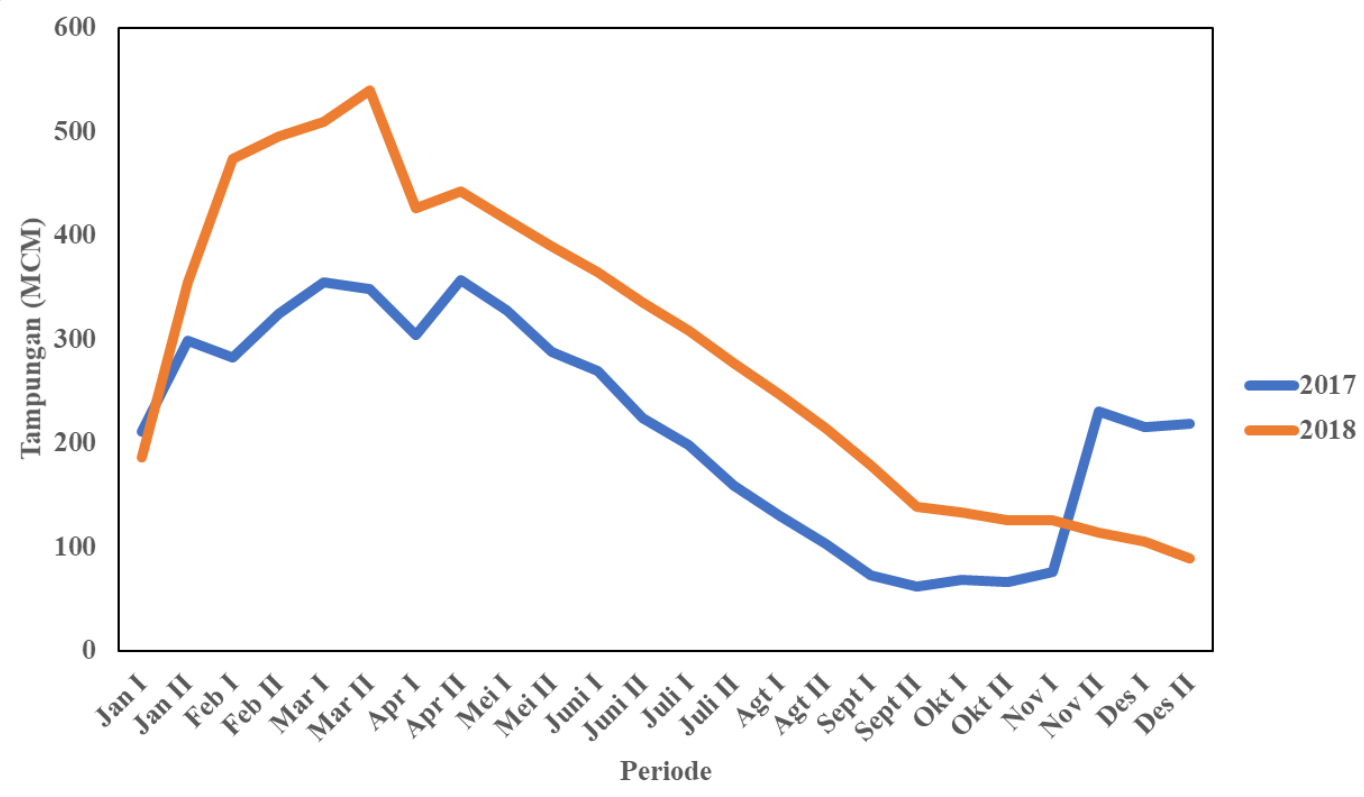

Gambar 7. Tampungan Waduk Gadjah Mungkur Tahun 2017 dan Tahun 2018

Perhitungan elevasi dengan menggunakan dua (2) persamaan yaitu Persamaan (2) dan Persamaan (4) dapat dilihat pada Tabel 2, Gambar 8 dan Gambar 9, yang menyajikan hubungan antara tampungan dan elevasi waduk pada tahun dan bulan yang bersesuaian. 
REKOnSTRUKSI TADULAKO: Civil Engineering Journal on Research and Development, Vol. 2(2), September 2021

Tabel 2. Perhitungan elevasi Waduk Gadjah Mungkur

\begin{tabular}{cccccccc}
\hline Tahun & Tampungan & Elevasi (2) & Elevasi (4) & Tahun & Tampungan & Elevasi (2) & Elevasi (4) \\
\hline $\mathbf{2 0 1 7}$ & MCM & $\mathbf{m}$ & $\mathbf{m}$ & $\mathbf{2 0 1 8}$ & MCM & $\mathbf{m}$ & $\mathbf{m}$ \\
\hline Jan I & 211.51 & 132.44 & 131.96 & Jan I & 186.54 & 131.81 & 131.35 \\
\hline Jan II & 298.94 & 134.64 & 133.81 & Jan II & 354.97 & 136.06 & 134.83 \\
\hline Feb I & 283.00 & 134.24 & 133.50 & Feb I & 474.13 & 138.06 & 136.81 \\
\hline Feb II & 324.14 & 135.28 & 134.28 & Feb II & 495.63 & 138.60 & 137.12 \\
\hline Mar I & 355.33 & 136.06 & 134.84 & Mar I & 509.89 & 139.73 & 137.32 \\
\hline Mar II & 348.13 & 135.88 & 134.71 & Mar II & 540.37 & 139.96 & 137.74 \\
\hline Apr I & 304.62 & 134.79 & 133.92 & Apr I & 426.34 & 137.85 & 136.09 \\
\hline Apr II & 356.94 & 136.10 & 134.86 & Apr II & 442.34 & 138.26 & 136.34 \\
\hline Mei I & 327.51 & 135.36 & 134.34 & Mei I & 415.11 & 137.57 & 135.92 \\
\hline Mei II & 287.53 & 134.36 & 133.59 & Mei II & 389.90 & 136.94 & 135.51 \\
\hline Juni I & 269.80 & 133.91 & 133.23 & Juni I & 364.69 & 136.30 & 135.09 \\
\hline Juni II & 223.99 & 132.75 & 132.25 & Juni II & 335.57 & 135.57 & 134.59 \\
\hline Juli I & 198.21 & 132.10 & 131.64 & Juli I & 308.39 & 134.88 & 134.09 \\
\hline Juli II & 159.70 & 131.13 & 130.64 & Juli II & 277.44 & 134.10 & 133.50 \\
\hline Agt I & 130.21 & 130.39 & 129.78 & Agt I & 246.66 & 133.33 & 132.87 \\
\hline Agt II & 103.09 & 129.71 & 128.87 & Agt II & 214.51 & 132.52 & 132.16 \\
\hline Sept I & 73.21 & 128.95 & 127.69 & Sept I & 178.52 & 131.61 & 131.29 \\
\hline Sept II & 61.75 & 128.67 & 127.17 & Sept II & 138.89 & 130.61 & 130.21 \\
\hline Okt I & 68.49 & 128.84 & 127.48 & Okt I & 132.96 & 130.46 & 130.03 \\
\hline Okt II & 66.39 & 128.78 & 127.39 & Okt II & 125.61 & 130.28 & 129.81 \\
\hline Nov I & 75.49 & 129.01 & 127.79 & Nov I & 126.17 & 130.29 & 129.83 \\
\hline Nov II & 231.11 & 132.93 & 132.41 & Nov II & 113.56 & 129.97 & 129.43 \\
\hline Des I & 215.70 & 132.55 & 132.06 & Des I & 105.59 & 129.77 & 129.16 \\
\hline Des II & 218.28 & 132.61 & 132.12 & Des II & 89.40 & 129.36 & 128.58 \\
\hline & Rerata & 132,56 & 131,68 & & Rerata & 134.29 & 133,32 \\
\hline & & & & & &
\end{tabular}

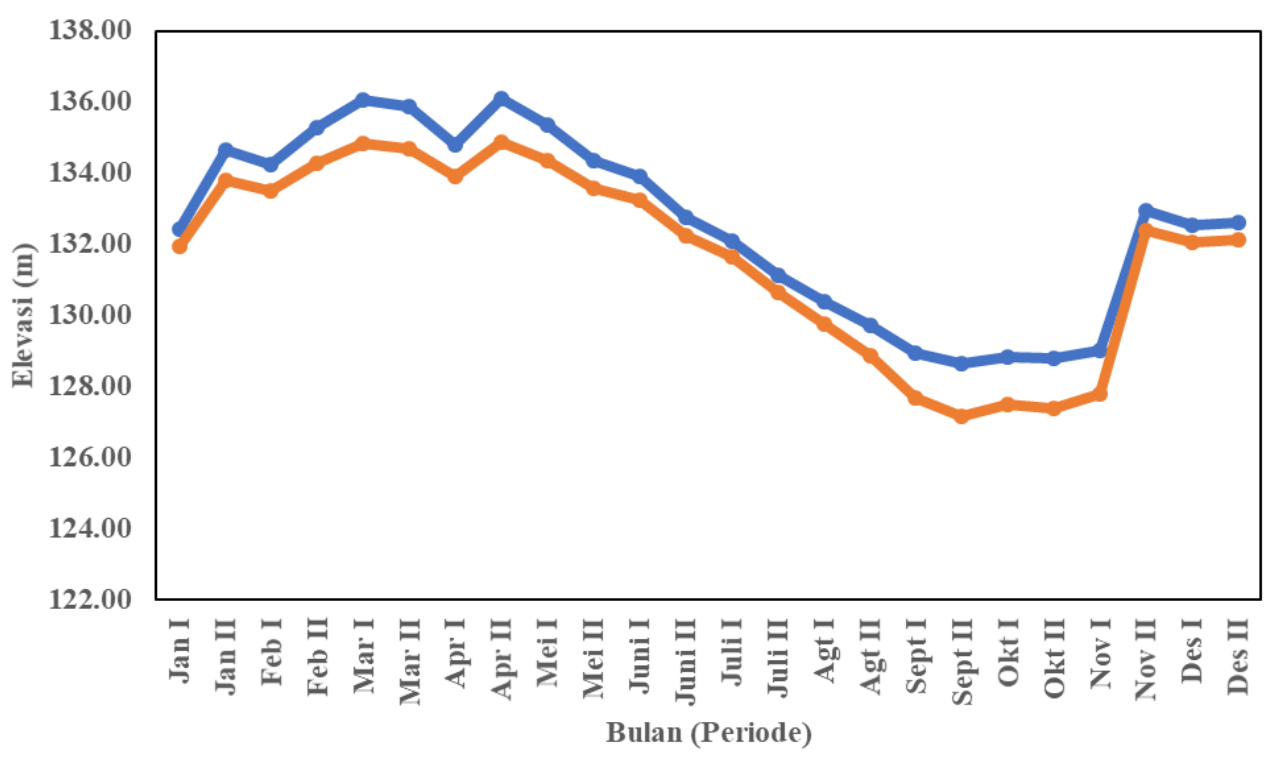

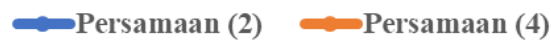

Gambar 8. Elevasi akhir Waduk Gadjah Mungkur pada Tahun 2017 


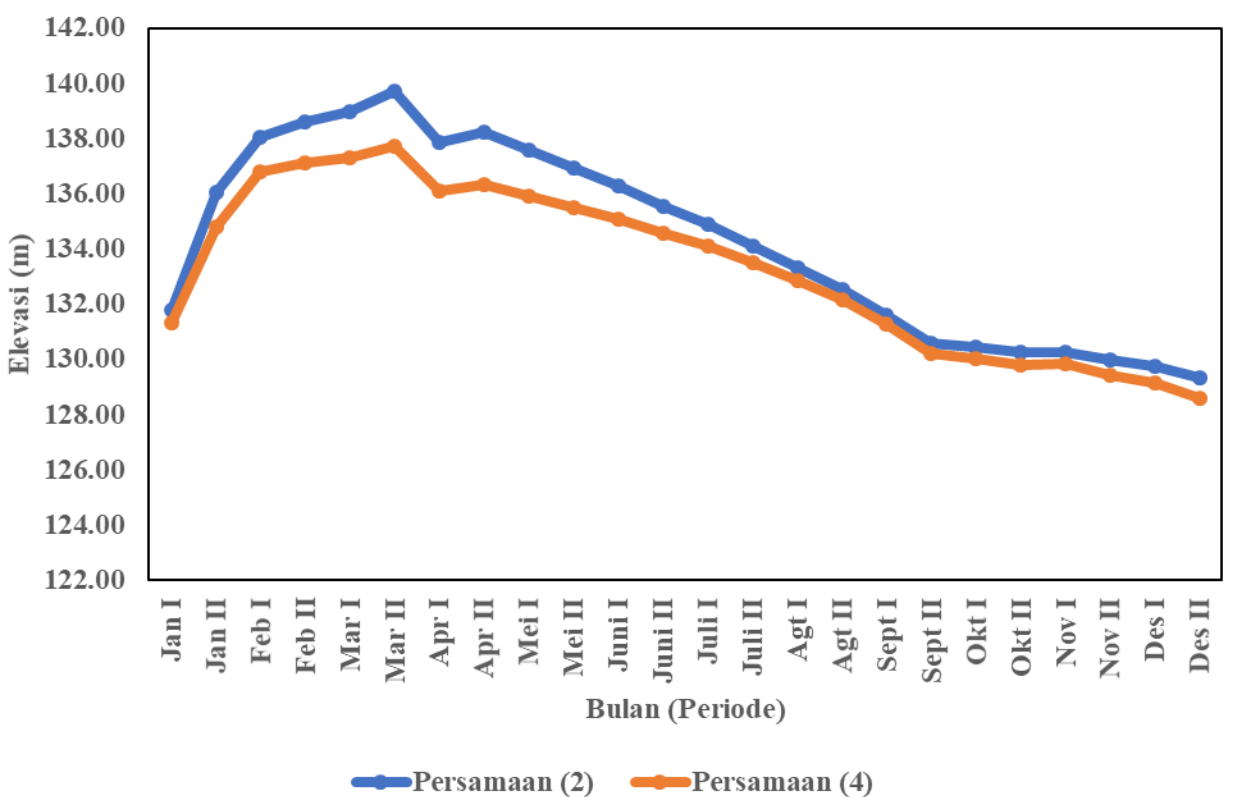

Gambar 9. Elevasi akhir Waduk Gadjah Mungkur pada Tahun 2018

Gambar 8 dan Gambar 9 menunjukkan bahwa nilai elevasi yang terbentuk pada Persamaan (2) dan Persamaan (4) tidak memiliki perbedaan yang cukup signifikan. Meskipun pada Gambar 8 terlihat bahwa elevasi tertinggi adalah bulan Maret yang memiliki hasil yang berbeda dengan Gambar 9 yaitu pada bulan April, dan juga elevasi terendah pada dua (2) tahun tersebut yaitu pada tahun 2017 dan tahun 2018 berada pada bulan berbeda, namun pola fluktuasi grafik yang terbentuk tetap tidak jauh berbeda atau tidak memiliki perbedaan yang cukup signifikan. Pada bulan April, maka grafik elevasi mulai mengalami penurunan hingga November, meskipun setelah November, pada tahun 2018, grafik elevasi mengalami kenaikan. Namun, hasil yang diberikan juga masih pada ambang atau elevasi yang aman dalam pemberian air atau pelepasan air dari Waduk Gadjah Mungkur.

Elevasi merupakan salah satu hal yang menjadi pertimbangan dalam pembukaan pintu untuk mengalirkan air dari waduk ke hulu yang nantinya hendak dialirkan kembali untuk kebutuhan sehari-hari seperti air irigasi dan air baku. Adanya Wosusokas akan menambah kebutuhan air yang diampu oleh waduk, namun dari analisis pada Tabel 2, Gambar 8 dan Gambar 9 terlihat bahwa Waduk Gadjah Mungkur masih mampu mengampu debit untuk kebutuhan air jaringan pipa transmisi Wosusokas yang nantinya akan dialirkan ke daerah-daerah yang menjadi jangkauan dari Wosusokas yaitu Wonogiri, Sukoharjo, Solo, dan Karanganyar.

\section{Kesimpulan}

Analisis sederhana ketersediaan air pada Waduk Gadjah Mungkur akibat pengaruh pembangunan intake dan jaringan pipa transmisi Wosusokas ini menghasilkan bahwa Waduk Gadjah Mungkur masih mampu untuk mengampu dan menambah fungsinya dalam memenuhi kebutuhan air baku bagi daerah-daerah yang dalam rencananya akan dijangkau oleh Wosusokas, dengan debit rencana yaitu 1,45 $\mathrm{m}^{3} / \mathrm{s}$. Hasil analisis juga menunjukkan bahwa adanya tampungan dan elevasi Waduk Gadjah Mungkur masih dalam kondisi mampu dan aman dengan adanya jaringan pipa transmisi Wosusokas. Meskipun begitu, kenaikan elevasi pada awal tahun harus diantisipasi dengan baik, dikarenakan dari hasil analisis yang didapatkan, terlihat bahwa pada awal-awal tahun tersebut adalah musim penghujan dan elevasi muka air menyentuh angka di atas $+138,0 \mathrm{~m}$

Perlunya tinjauan lebih lanjut terkait stabilitas, keamanan bendungan, dan lain-lainnya menjadi suatu hal yang patut untuk dipertimbangkan, sehingga analisis sederhana ini mendapat pertimbangan dan pandangan dari analisis lainnya, seperti adanya analisis pengaruh dalam menaikkan elevasi pelepasan air waduk terhadap kebutuhan air yang bertambah, kemudian juga pedoman atau peraturan baru terhadap pola operasi baru Waduk Gadjah Mungkur terkait dengan jaringan pipa transmisi Wosusokas, dan halhal pendukung lainnya.

\section{Daftar Pustaka}

[1] R. Jayadi, Pengaturan Release Waduk Metode SOR. Materi dipresentasikan pada Kuliah Teknik Sumber Daya Air, Yoyyakarta: Departemen Teknik Sipil dan Lingkungan Universitas Gadjah Mada, 2019.

[2] Anonim, Proyek Pembangunan Intake dan Jaringan Pipa Transmisi Wosusokas di Kabupaten Wonogiri, Solo: Booklet Proyek Wosusokas, 2016.

[3] http://ciptakarya.pu.go.id/pspam/?section=berita\&id= 777 (diakses tanggal 8 Agustus 2021)

[4] Nippon Koei CO., LTD, Detailed Design of Structural Countermeasures for Sedimentation on Wonogiri Reservoir-Edisi 1, Solo: BBWS Bengawan Solo, 2010.

[5] B.K.P. Cantik, S.D. Mulyadi, and M.I. Pratama, "Evaluasi Pola Operasi Waduk Wonogiri dengan 
Adanya Jaringan Pipa Transmisi Wosusokas", JTD Universitas Pradita, vol. 3, no. 1, p. 20, 2021.

[6] R. Saily and A. Hamidi, "Evaluasi Distribusi Air Baku Pada Waduk Wonosari di Kabupaten Bengkalis", Indonesian Journal of Construction Engineering and Sustainable Development (CESD), vol. 3 no. 1, p. 23, 2020 .

[7] W. Andita and S. Lipu, "Analisis Ketersediaan Air DAS Sausu Untuk Kebutuhan Air Pada D.I. Sausu Bawah, Kabupaten Parigi Moutong", RTCEJRD, vol. 1, no. 2, p. 63, 2020.

[8] I.K. Sari, L.M. Limantara, and D. Priyantoro, "Analisa Ketersediaan dan Kebutuhan Air pada DAS Sampean", Jurnal Teknik Pengairan, vol. 2 no. 1, p. 29, 2011

[9] R. Kalbuardhi and D. Suwarno, "Analisis Ketersediaan Air Waduk Jatiluhur Sebagai Dasar Penerapan Pola Operasi Pembangkit Listrik Tenaga Air", G-SMART: Jurnal Teknik Sipil Unika Soegijapranata, vol. 2 no. 2, p. 51, 2018.

[10] D.P. Pradwipa, R. Jayadi, and Istiarto, "Kajian Pemanfaatan Sumberdaya Air Waduk Serbaguna Jatigede, Jawa Barat", RENOVASI: Rekayasa Dan Inovasi Teknik Sipil, vol. 4 no. 2, p. 10, 2019.
[11] Y. Mekiuw, "Studi Neraca Air Waduk Lapangan (Long Storage) di Desa Semangga Jaya Kabupaten Merauke", AGRICOLA, vol. 3 no. 2, p. 72, 2013.

[12] Winasis, H. Prasetijo, and G.A. Setia, "Optimasi Operasi Pembangkit Listrik Tenaga Air (PLTA) Menggunakan Linear Programming Dengan Batasan Ketersediaan Air", Dinamika Rekayasa, vol. 9 no. 2 , p. 1, 2013.

[13] L.M. Limantara and W.R. Putra, "Analisa Keandalan Tampungan Waduk di Embung Tambak Pocok Bangkalan”, Jurnal Teknik Sipil, vol. 23 no. 2, p. 127 , 2016 .

[14] Suripto, "Analisis Potensi dan Pemanfaatan Air Waduk Cipancuh di Kabupaten Indramayu", Poli Teknologi, vol. 10 no. 1, p. 22, 2011.

[15] R.B. Sukmara, J.J. Pratama, and Ariyaningsih, "Analisis Ketersediaan Dan Kebutuhan Air Baku Kota Balikpapan Studi Kasus: Waduk Manggar, Kota Balikpapan", ETERNITAS: Jurnal Teknik Sipil, vol 1, no 1, p. 7, 2020. 